\title{
Clinical thresholds in food allergy and their application in risk assessment management
}

\author{
Geert Houben \\ From Food Allergy and Anaphylaxis Meeting 2011 \\ Venice, Italy. 17-19 February 2011
}

In the EU, the use as ingredients in food of several major allergens or products derived thereof is to be labelled according to EU Directives 2003/89/EC and 2006/142/EC. This obligation only concerns the use of allergenic ingredients according to recipe. However, allergens may also be present in food due to cross contamination in food production facilities or contamination of raw materials or ingredients. Pele et al. (2007), VWA (2007) and Spanjersberg et al. (2010) have demonstrated the presence of considerable amounts of allergens in many food products that did not carry any warning for the presence of these allergens. The presence of allergens without accompanying warning obviously poses a risk to allergic consumers, as these individuals have no opportunity to judge the appropriateness of the concerning food products for them to eat (Spanjersberg et al. 2010, Sheth 2010).

In contrast to the absence of any warning on many products that do contain certain allergens, there appear to be many food products in the market that carry a precautionary (often called "may contain") labelling to warn consumers for the possibility of unintended presence of allergens. In many cases, such precautionary labelling seems not to be based on a relevant risk but is meant as a disclaimer in case the producer cannot exclude a risk for $100 \%$. This seems to lead to a nonselective use of this precautionary labelling, which causes other problems, such as a reduced food choice for allergic consumers and devaluation of the information value of such warning (Health Council of the Netherlands 2007). The consequence of the dilemma's described above is that there are many products in the market with a warning while there is no or only a very small (negligible) risk and that, at the same time, there are many products without a warning that contain

Business Line Food Safety TNO, Zeist, Netherlands (sometimes very high amounts of) allergens. Precautionary labelling seems to provide the allergic consumers with no useful information anymore. Risk analysis principles can be applied to solve this problem and to bring guidance, harmonisation and transparency in information delivery regarding possible unintended presence of allergens in food products. For practical application of a risk analysis-based approach, a risk assessment methodology is essential.

We developed a risk assessment method to quantify the number of allergic consumers that may suffer allergic reactions to specific levels allergens in food products or to calculate concentration action levels that can be based on predefined tolerable risks (Spanjersberg et al. 2007 and 2010, Kruizinga 2008). Clinical threshold data are of major importance in this methodology. Clinical threshold data are available for most major food allergens for which management of cross contamination risks is needed. Suitability for use in risk assessment will be discussed and it will be demonstrated how such clinical thresholds can be used in allergen risk assessment and risk management.

Published: 12 August 2011

\section{References}

1. EU Directive 2003/89/EC of the European Parliament and of the Council of 10 November 2003, amending Directive 2000/13/EC as regards indication of the ingredients present in foodstuffs. Official Journal of the European Union 2003, L 308:15-18.

2. EU Directive 2006/142/EC amending Annex Illa of Directive 2000/13/EC of the European Parliament and of the Council listing the ingredients which must under all circumstances appear on the labelling of foodstuffs. Official Journal of the European Union 2006, L 368:110-111.

3. Health Council of the Netherlands: Food Allergy. Report of the health Council of the Netherlands, publication number 2007/07 The Hague, The Netherlands; 2007.

4. Kruizinga, et al: Probabilistic risk assessment model for allergens in food: sensitivity analysis of the minimum eliciting dose and food consumption. Food and Chemical Toxicology 2008, 46:1437-1443. 
5. Pele, et al: Peanut and hazelnut traces in cookies and chocolates: relationship between analytical results and declaration of food allergens on product labels. Food Additives and Contaminants 2007, 24:1334-1344.

6. Sheth, et al: Role of food labels in accidental exposures in food-allergic individuals in Canada. Ann Allergy Asthma Immunol 2010, 104:60-65.

7. Spanjersberg, et al: Concentrations of undeclared allergens in food products can reach levels that are relevant for public health. Food Additives and Contaminants 2010, 27:169-174.

8. Spanjersberg, et al: Risk assessment and food allergy: the probabilistic model applied to allergens. Food and Chemical Toxicology 2007, 45:49-54.

9. WWA: Fact sheet. Dutch Food and Consumer Product Safety Authority; 2007.

doi:10.1186/2045-7022-1-S1-S65

Cite this article as: Houben: Clinical thresholds in food allergy and their application in risk assessment management. Clinical and Translational Allergy 2011 1(Suppl 1):S65.

\section{Submit your next manuscript to BioMed Central} and take full advantage of:

- Convenient online submission

- Thorough peer review

- No space constraints or color figure charges

- Immediate publication on acceptance

- Inclusion in PubMed, CAS, Scopus and Google Scholar

- Research which is freely available for redistribution

Submit your manuscript at www.biomedcentral.com/submit
Ciomed Central 